\title{
Cooperators Satisfaction with Cooperative Society Housing Activities in Jos
}

\author{
Aishatu Adamu Mazadu ${ }^{1}$, Maryam Salihu Muhammad ${ }^{2}$, Nneoma Iroaganachi ${ }^{2}$ \\ 1 University of Jos \\ P. M. B 2084, Jos, Nigeria \\ ${ }^{2}$ Abubakar Tafawa Balewa University \\ Tafawa Balewa Way, P. M. B. 0248, Bauchi, 740272, Nigeria
}

DOI: $10.22178 /$ pos. $73-4$

JEL Classification: 018

Received 20.07.2021

Accepted 28.08.2021

Published online 31.08.2021

Corresponding Author:

Aishatu Adamu Mazadu

aishatumazadu@gmail.com

(C) 2021 The Authors. This article

is licensed under a Creative

Commons Attribution 4.0

License @ (1)

\begin{abstract}
Most public workers in Nigeria have always faced the problem of housing either during service or after retirement. This is because the mechanism put in place by the government for tackling the housing problem has not met their expectations. Due to that, workers started using alternative means to solve their housing needs. This study measured the level of housing activities carried out by the cooperative society and assessed cooperators' satisfaction with the activities in Plateau State, Nigeria. The study was based on various questionnaire survey methods conducted on institution-based cooperative societies engaged in cooperator housing activities. Data was collected from Jos University Teaching Hospital JUTH multipurpose cooperative society in the State. Data were analysed with descriptive statistical tools using mean ranking, and a 5-Point Likert scale was used to determine the level of each activity. It was found that housing development, direct purchases of houses, private-public projects and building materials purchase ranked highest.

In contrast, processing land and building documents, housing loans, and land allocation were the least ranked contrary to popular belief that cooperative societies only achieved land allocation and granting of housing loans. Also, the respondents were most satisfied with housing development, directly purchased houses, building materials purchase, transaction cost, while their level of satisfaction on interest to be paid on loans for housing, cost of loan recovery, processing of land and building document and land allocation were ranked least respectively. Therefore, the study concluded that cooperators satisfaction should be given consideration in all activities to improve patronage for their various housing needs at all times.
\end{abstract}

Keywords: cooperative societies; housing activities; cooperators satisfaction.

\section{INTRODUCTION}

Housing is a global trend facing developed and developing wealthy and emerging nations [27]. It is both an investment and consumption commodity [16], being a key source of economic growth for countries such as China [42] and in countries such as Britain and America, constituting a significant source of household wealth [8]. Researchers [44] estimated total housing needs in Africa at around 4 million units per year, with over $60 \%$ of the demand required to accommodate urban residents. The figure may likely rise to 5 million per year in the cities. Nigeria housing shortage as at December 2018 estimated to a staggering 20 million units [27], which is about 3 million increases compared with the 17 million units earlier reported by [46]. Hence, the need for all the stakeholders to join hands in providing housing needs for the populace.

Cooperative societies housing activities are approaches aimed at assisting cooperators in having their own houses in any country by the cooperative society [14]. In Nigeria, government and private corporations have embarked upon several housing schemes at different levels to provide houses for their citizens. Yet, housing problems keep persisting, especially for public servants in the country. For many Nigerians, the desirability 
of having or living in decent houses is as strong as the reality of its imprecision. Inability to afford this critical asset is mainly a root cause of poor housing conditions in Nigeria [3]. Although housing policies by the government began before the country's independence in 1960, before that period, housing was provided through communal systems in which communities tried to preserve their values while providing houses as desired by the community [3]. Between 1928 to date, the Nigerian housing sector has witnessed developmental strides in government efforts towards improved housing through legislation, reforms, strategies and policies [22]. Authors [17] reported that this challenge is imposed by rapid population growth and inadequate mechanisms for effective improvement. For example, over 19 years (1975-1994), only 81,750 (42.70\%) houses were provided out of the 570,000 units proposed within that period [22]. This number represents less than $50 \%$ success over a significant time, and Government efforts to improve housing are evolving slowly [22]. Hence, it is evident that there have been continued efforts generally, but with little impact and improvement [4, 14]. Nigerian policy implementation and strategies for housing have generally been deficient in meeting stakeholders housing needs. Presently, housing stands at two dwelling units per 1000 people [3] against the United Nations recommended 8-10 per 1000.

The reports $[25,26]$ reported that the housing deficit in the State is estimated between 450,000 to 500,000 units for the entire State, with a population of about 900,000 residents based on the 2006 census and 240000 deficits for the more excellent Jos's master plan. Since the state lowcost housing units of the 1970s and the Shagari mass housing scheme in the 1980's not much has been done in terms of direct provision of mass housing units for citizens in Plateau state. Frequent occurrence of crises in the State led to the destruction of houses and properties without any proper plan for erecting new ones or rehabilitating the old ones; this increases demand for houses that out weight its supply in the State. The resultant effect of this shortfall led to high rental prices, overcrowding, uncontrolled squatter settlements and slums. The author [43] opined that urbanisation and demand for houses are positively correlated, and as cities expand, so do the need for more housing. These needs have not been met in most developing countries, especially in Nigeria. Authors [36] concluded that hous- ing shortage in developing countries has escalated to unprecedented rates making the percentage of slum dwellers extremely high.

However, one of the solutions being explored by underprivileged groups is cooperative societies housing. It has been said to have played vital roles in housing in some countries, but the concern is the activities of cooperative societies in the area of housing in Nigeria [40]. According to [11], cooperative societies housing activities are alternative housing approaches that combine the collaborative practices and methods with the principles and processes of housing to provide housing for cooperators. In [44] report, the United Nations' Secretary-General summarised the significance of the cooperative sector to the economy as follows: "Cooperative Societies support stability, social cohesion, and give life to the concepts of corporate responsibility and citizenship. In addition, they provide essential services, ranging from housing to health care that strengthens community development". Although, according to [37], the idea of housing through cooperative societies is not new, what is new is that the model has been repackaged and reinvigorated in recent times in many countries by incorporating various formats and techniques to improve access to housing among the cooperators.

Cooperative societies housing activities is an increasingly popular housing model across the developed countries, particularly for social housing $[23,31,39]$. According to $[2,14]$, this vehicle of housing activities has been practised in different countries such as Italy, United Kingdom, Zambia, Sweden, Philippines, Denmark, Norway, Canada and South Africa. Authors [14, 15] stated that cooperatives societies could be a viable mechanism to positively impact funding housing in urban centres, especially to workers of public institutions in Nigeria. Therefore, the activities of cooperative societies towards the economic and financial empowerment of members have been a subject of investigation by researchers. However, in the area of housing activities by the cooperatives societies have been limited mainly in Nigeria. For instance, authors [1, 2, 15], among others, averred that the involvement of cooperative societies in housing activities has been successful. On the other hand, [29] argued that cooperative societies have not significantly impacted the $\mathrm{Ni}$ gerian housing sector. Their opinion is contradicting, and it becomes imperative to undertake a decisive investigation on housing activities by 
cooperative societies primarily to determine the cooperators level of satisfaction with the housing activities in Jos, Plateau State.

\section{Literature review}

Cooperative Societies Housing Activities. The history of cooperative society's participation in the housing sector across the world is framed by three major factors: the political structure of each particular country, the impact of the two world wars and lastly, the rate of urbanisation. Although, [38] traced the origin of cooperative societies' participation in housing activities to the beginning of the 19th century where they were formed to respond to the high demand for housing across Europe, a thorough review of the subject matter reveals that this participation has been facilitated in advanced countries by the formation and growth of cooperative housing structures. Since the end of the 2nd World War, policy measures such as favourable legislation, subsidies and tax incentives were implemented to increase homeownership across Europe. These were strengthened by positive civic attitudes towards homeownership [19].

According to [6], in Nigeria, cooperative societies emerged as an option explored by the majority, primarily low-income groups and somewhat alienated by the privileged minority that controls an economy's resources. Societies have become a strong, vibrant and viable economic alternative in a period when many people feel helpless, powerless or disenfranchised to change their living conditions. Cooperative societies are formed principally to meet peoples' mutual needs based on the idea that a group of people can achieve goals that none of them could achieve alone. The formation and goal of cooperative societies are not to meet unessential collective or individual needs. Instead, it aims to provide basic needs that otherwise might take a long time to realise or are completely unaffordable without assistance [36].

Authors [1] described cooperative societies housing as "having to do with the pooling of resources together to finance the erection of dwelling housing for members of the cooperative association and at a higher level of organisation in the construction of large multi-unit structure which would be shared out in units to all members of the association". Resource [10] described a housing cooperative as a 'form of ownership where individuals own shares in a corporation that owns or controls the land and buildings that provide the housing. The shared ownership model entitles the cooperative members to occupy a unit within the cooperative and specific rights and responsibilities. On their part, for [28], within the cooperative framework, housing cooperatives can be thought of as service or consumer cooperatives where members are residents and therefore "consumers' of the (housing) service. The cooperatives own the properties and, after that, let them to members; each member must purchase a share and sign a legal occupancy agreement that outlines membership expectations and member rights.

Housing activities by cooperative societies are various methods in which they assist members to built their own houses or directly purchase the houses to solve their housing problems. Unlike the government and profit-oriented private sector, the cooperative method of housing emphasises end users' participation from the commencement of the process [38]. This is made possible based on the principles and values that govern the operation and activities of cooperative societies. Authors [34] stated that housing activities by cooperative societies include land acquisition, houses developed and allocated to cooperators at a subsidised rate, building materials procurement, direct housing purchase, and direct private project and providing loans for housing to cooperators. Efforts directed at meeting the housing objectives of cooperative members have resulted in different strategies depending on the objective, financial capacity, and level of assistance received [38].

Consequently, different types of strategic intervention in housing have been observed among the cooperatives. Generally, cooperative societies adopt different methods to meet the housing objectives of members based on society's nature, focus, or purpose. In the developed countries, these methods have been broadly grouped into four, achieved by altering the basic legal and finance structure to suit the organisation's autonomy [34]. First, the market rate or equity cooperatives, where members do not own a specific piece of property but a share of the cooperative corporation that owns the estate. Members are also permitted to sell their shares at total market values, thereby accruing a market rate of return. Second, a limited-equity cooperative that meets members' housing needs by combining the equity contribution of cooperators with grants or subsidies from supporting institutions to provide 
housing units for its members North Country Cooperative Foundation [30]. The third is the leasing cooperative. A leasing cooperative takes a long lease from an investor, a landlord or a nonprofit organisation and operates the building collectively as a cooperative [30]. The fourth category is the mutual housing association, a non-profit corporation set up to develop, own, and operate housing. Generally, the association is owned and controlled by the residents of the housing produced. The author [7] asserted that cooperative solid and mutual housing sectors exist in various countries worldwide. The Commission on Cooperative and Mutual Housing defines mutual housing organisation as enabling residents to have the right to become members, control or participate in governance, and exercise control over their housing environment, neighbourhood, and community [7].

In Nigeria, cooperatives societies meet the housing need of cooperators in some ways. According to $[1,36,46]$, such methods include model housing construction similar to government housing schemes, granting of house building loans, the direct construction of housing units which are allocated to members at subsidised rates, acquisition of land for cooperators, processing of land and building documents and bulk procurement of building materials. Thus, cooperatives aid members' home acquisition wholly, partly or gradually depending on society's objectives, focus, and financial capacity. However, the concept of market rate, limited equity and leasing are not common in the Nigerian context, possibly because of the level of sophistication of the economy.

Cooperators' Satisfaction. Satisfaction is the person's feelings of pleasure or disappointment from comparing a product's perceived performance (or outcome) to their expectations [12]. This definition makes it clear that satisfaction is a function of perceived performance and expectations. If the performance falls short of expectations, the cooperator is dissatisfied; if the performance matches the expectations, the cooperator is satisfied. If the performance exceeds expectations, the cooperator is highly satisfied or delighted [12].

Author [35] asserted that cooperators satisfaction is a precursor of improved performance and cooperator retention for any cooperative society. In part, the strength of a cooperative depends on its ability to mobilise its resources and members in gaining market share and achieving economic growth and maintaining member commitment, satisfaction, and retaining them. Satisfied, highly committed members are more likely to support their cooperative by participating in all cooperative activities. The reverse occurs when members are unhappy. Member's goals, what they desire from their cooperatives are critically related to why they joined the cooperative in the first place. These goals also affect member satisfaction with the cooperative, commitment to it, and participation in its activities [12]. The ability of a cooperative to meet its members' expectations depends on whether management effectively evaluates membership needs. Often, they do not, and there are several reasons for this. One notion is that of "assumed similarity," cooperative official's belief that the interests of the general membership must be similar to their own and, therefore, there is no need to investigate them separately. Secondly, member-officer communications may be poor [6]. The third is reported by [18]. As a divergent set of member objectives both between and within cooperatives, members' attitudes towards their cooperatives significantly impact their cooperative participation behavioural intentions.

The researcher [32] opined that various internal and external factors might influence the level of member satisfaction. Ceteris paribus, the more positive attitude one holds towards an organisation, the more likely it is that the person will patronise or use a service from it. Author [33] submitted that to achieve high levels of cooperators satisfaction requires cooperative society to continually monitor and examine the experiences, opinions, and suggestions of their cooperators and other people who are likely to be potential members, as democratic organisations, cooperatives rely on cooperators patronisation for the realisation of their distinctive character. Authors [14] reported that cooperators expressed their satisfaction with housing cooperative loans compared to the National Housing Fund. Author [15] also revealed that cooperators expressed their satisfaction with an interest rate, affordability, transaction cost, availability and collateral for housing finance. However, in housing activities, cooperators need to be satisfied with housing development, cost of labour, building materials purchased, houses directly purchased, interest to be paid on loans for housing, cost of loan recovery if members default, transaction cost, processes of land and building document, land allocated etc. 
This study measured cooperators' satisfaction with all the housing activities carried out by cooperative societies in Jos's plateau state.

\section{METHODOLOGY}

This research was carried out in Plateau State; the study's target population was cooperators of Jos University Teaching Hospital (JUTH) Multipurpose Cooperative Society. The sample frame obtained from JUTH Multipurpose cooperative society is 3000 cooperators, but only 2200 members are active; therefore, only the active members were considered for this study. The sample size of 327 used for this research was chosen using the [24] sample table. Multistage sampling was used; this involved taking samples in stages using smaller and smaller units at each stage. Purposive sampling was used at the first stage to select only institutions with a cooperative society engaged in housing activities. This sampling technique is used when a researcher chooses a sample that suits their research needs [13]. Then simple random sampling technique was also adopted. This is because it gives each equal chance or probability of being selected, reducing selection bias [13]. Three hundred twenty-seven close-ended questionnaires were distributed to the cooperators of the cooperative societies to generate data for the study.

The data obtained from the administered questionnaire were analysed with descriptive statistical tools using mean ranking. A 5-Point Likert scale was used to determine the level of each activity and the cooperator's satisfaction. The analysis of the data was done using Statistical Package for Social Science (SPSS).

\section{RESULTS AND DISCUSSION}

Level of Housing Activities by Cooperatives Society in the Study Area. The findings from the rank ordering of the seven type constructs on the level of housing activities by cooperatives society in the study area (Table 1) reveals that housing development ranked1st, direct housing purchase 2nd, private housing project 3rd and building material procurement ranked 4th, respectively has the highest rank. In contrast, land and building documents ranked 5 th, housing loans for members 6 th and acquisition of land for members ranked 7 th respectively, were the least ranked. These findings are in line with that of cooperative socie- ties that were recognised by the State and supported in their drive to provide housing for the teeming refugees, migrants and citizens [38]. As a result, housing cooperatives became the preferred housing provision and management structure after privatising apartments [38].

Table 1 - Level of Housing Activities by Cooperative Societies

\begin{tabular}{|l|c|c|c|l|}
\hline & Mean & $\begin{array}{c}\text { Std. } \\
\text { Deviation }\end{array}$ & Ranking & Remarks \\
\hline $\begin{array}{l}\text { Housing } \\
\text { development }\end{array}$ & 3.1205 & .86799 & 1st & Moderate \\
\hline $\begin{array}{l}\text { Direct } \\
\text { housing } \\
\text { Purchase }\end{array}$ & 2.7362 & .60937 & 2nd & Moderate \\
\hline $\begin{array}{l}\text { Private } \\
\text { housing } \\
\text { project }\end{array}$ & 2.4072 & .73677 & 3rd & Low \\
\hline $\begin{array}{l}\text { Building } \\
\text { material } \\
\text { procurement }\end{array}$ & 2.0912 & .74414 & 4 th & Low \\
\hline $\begin{array}{l}\text { Land and } \\
\text { building } \\
\text { document }\end{array}$ & 1.2638 & .44144 & 5 th & Very low \\
\hline $\begin{array}{l}\text { Housing loans } \\
\text { for members }\end{array}$ & 1.1759 & .38135 & 6 th & Very low \\
\hline $\begin{array}{l}\text { Acquisition of } \\
\text { land for } \\
\text { members }\end{array}$ & 1.0586 & .23532 & 7 th & Very low \\
\hline
\end{tabular}

The findings from rank ordering by the eight type constructs on cooperators level of satisfaction with housing activities by cooperative societies in the study area (Table 2) revealed that cooperators are highly satisfied with housing development ranked 1st, directly purchased houses 2 nd, building materials purchase $3 \mathrm{rd}$, transaction cost 4th respectively, ranked highest while their level of satisfaction on interest to be paid on loans for housing ranked 5th, cost of loan recovery 6th, processing of land and building document 7 th and land allocation 8th respectively, were the least ranked. These findings align with [14] reported that cooperators expressed their satisfaction with housing cooperative loans compared to the National Housing Fund (NHF). On the other hand, [15] also revealed that cooperators expressed their satisfaction with an interest rate, affordability, transaction cost except for availability and collateral for the cooperative loan, which they express dissatisfaction. 
Table 2 - Level of Cooperators Satisfaction with Housing Activities in the Study Area

\begin{tabular}{|l|c|r|r|l|}
\hline & Mean & $\begin{array}{c}\text { Std. } \\
\text { Deviation }\end{array}$ & Ranking & Remarks \\
\hline $\begin{array}{l}\text { Housing } \\
\text { development }\end{array}$ & 2.7068 & .70853 & 1st & Moderate \\
\hline $\begin{array}{l}\text { Directly } \\
\text { purchased } \\
\text { houses }\end{array}$ & 2.3225 & .79433 & 2nd & Low \\
\hline $\begin{array}{l}\text { Building } \\
\text { materials } \\
\text { purchase }\end{array}$ & 2.0586 & .48150 & 3rd & Low \\
\hline $\begin{array}{l}\text { Transaction } \\
\text { cost }\end{array}$ & 1.9739 & .57107 & 4 th & Low \\
\hline $\begin{array}{l}\text { Interest to be } \\
\text { paid on loans } \\
\text { for housing }\end{array}$ & 1.6482 & .53629 & 5 th & Very low \\
\hline $\begin{array}{l}\text { Cost of loan } \\
\text { recovery }\end{array}$ & 1.6482 & .58858 & 6th & Very low \\
\hline $\begin{array}{l}\text { Processing of } \\
\text { land and } \\
\text { building } \\
\text { document }\end{array}$ & 1.3811 & .48645 & 7 th & Very low \\
\hline $\begin{array}{l}\text { Land } \\
\text { allocation }\end{array}$ & 1.2052 & .40452 & $8^{\text {th }}$ & Very low \\
\hline
\end{tabular}

\section{CONCLUSIONS}

Cooperative societies are gradually becoming alternative mechanisms and a sure way of solving the housing problems of their cooperators. This is because cooperative societies housing activities, as revealed in the study, are limited to land allocation and housing loans as stated by most researchers but are also into development and many more. This has improved their capacity in solving housing problems in Plateau state.

Cooperators satisfaction in all activities is paramount. Therefore, cooperative societies should look into all housing activities and ensure the utmost satisfaction of cooperators based on their demands and needs. Also, cooperative societies need to source funds outside to hasten housing activities. Finally, the government should assist cooperatives with a low-interest rate fund to speed up housing activities since they are now considered an alternative mechanism in solving housing needs.

\section{REFERENCES}

1. Adedeji, Y. M. D., \& Abiodun O. O. (2012). An Evaluation of Accessibility of Low-Income Earners to Housing Finance in Nigeria. European Scientific Journal, 8(12), 80-95.

2. Adediji, Y. M. D. (2006). Affordable and Functional Housing in a Developing Economy: A case study of Nigeria. Journal of Land Use and Development Studies, 2(1), 113-120.

3. Ademiluyi, A. I. (2010). Public housing delivery strategies in Nigeria: a historical perspective of policies and programmes. Journal of Sustainable Development in Africa, 12(6), 153-161.

4. Ademiluyi, A. I., \& Raji, B. A. (2008). Public and Private Developers as Agents in Urban Housing Delivery in Sub-Saharan Africa: the Situation in Lagos State. Humanity\& Social Sciences Journal, 3(2), 143-150.

5. Ayedun, C. A., Oloyede, S. A, Ikpefan, A., Akinjare, A. O., \&. Oloke, C. O. (2017). Cooperative Societies, Housing Provision and Poverty Alleviation in Nigeria. Covenant Journal of Research in the Built Environment, 5(1), 69-81

6. Bello, A. (2005). The Role of Cooperative Societies in Economic Development. Retrieved from https://mpra.ub.uni-muenchen.de/23161/1/MPRA_paper_23161.pdf

7. Bliss, N. (2009). Bringing Democracy Home. Retrieved from https://www.housinginternational.coop/resources/bringing-democracy-home/

8. Boar, C., Gorea, D., \& Midrigan, V. (2017). Liquidity Constraints in the U.S. Housing Market. doi: $10.3386 / w 23345$

9. Bonaventure, N. H. (2003). The State of agricultural multipurpose cooperatives societies and rural development (Doctoral dissertation), University of Jos, Nigeria.

10. Chicago Mutual Housing Network. (2004). Affordable housing cooperatives. Conditions and prospects in Chicago. Retrieved from https://voorheescenter.red.uic.edu/wpcontent/uploads/sites/122/2017/10/2004-affordable-housing-cooperatives.pdf 
11. National Confederation of Cooperatives. (2004). Cooperatives in housing - starting housing projects a guide for cooperatives starting a housing project.

12. Dakurah, H. A., Goddard, E., \& Osuteye, N. (2005). Attitudes towards and Satisfaction with Cooperatives in Alberta: A Survey Analysis. Retrieved from https://www.researchgate.net/publication/23506299_Attitudes_Towards_and_Satisfaction_wit h_Cooperatives_in_Alberta_A_Survey_Analysis

13. Easton, V., \& McColl, J. (n. d.). Sampling. Retrieved from http://www.stats.gla.ac.uk./steps/glossary/sampling.html

14. Farouk, B. U. K., David, I. J., \& David, O. A. (2014). Savings and Credit Cooperative Societies (SCCs): A Panacea to Accessing Funds for Housing Development to Workers of Public Institutions in Nigeria. Journal of Economics and Sustainable Development, 5(23), 135-148.

15. Gbadeyan, R. A. (2011). Private Sector's Contributions to the Development of the Nigerian Housing Market. Current Research Journal of Social Sciences, 3(2), 104-113.

16. Glaeser, E., \& Gyourko, J. (2018). The Economic Implications of Housing Supply. Journal of Economic Perspectives, 32(1), 3-30. doi: 10.1257/jep.32.1.3

17. Ibem, E. O., \& Amole O. O. (2010). Evaluation of Public Housing Programmes in Nigeria: A Theoretical and Conceptual Approach. The Built \& Human Environment Review, 3, 88-92.

18. Iruguthu, E. W. (2014). Factors that influence customer satisfaction in savings and credit cooperatives (saccos) in Kenya: a case study of Balozi Sacco (Master's thesis). Retrieved from http://erepo.usiu.ac.ke/bitstream/handle/11732/56/Emily.pdf?sequence=1

19. Isebaert, J. (2014). The Belgian housing policy, its adverse effect on labour mobility and the negative externalities of homeownership. Retrieved from https://finances.belgium.be/sites/default/files/downloads/BdocB_2014_Q3e_Isebaert_fr.pdf

20. Johns, R. (2010, March). Likert scale and scales. Retrieved from https://dam.ukdataservice.ac.uk/media/262829/discover_likertfactsheet.pdf

21. Jos University Teaching Hospital. (2000). About. Retrieved from https://juth.org.ng/

22. Kabir, B., \& Bustani, S. (2008). A Review of Housing Delivery Efforts. Retrieved from www.gla.ac.uk/media/media_129767_en.pdf

23. Kareem, R. O., Arigbabu, Y. D., Akintaro, J. A., Badmus, M. A (2012). The Impact of Cooperative Society on Capital Formation. Habitat International, 25, 473- 492.

24. Krejcie, R. V., \& Morgan, D. W. (1970). Determining Sample Size for Research Activities. Educational and Psychological Measurement, 30(3), 607-610. doi: 10.1177/001316447003000308

25. Ministry of Commerce and Industry Plateau State. (2019). About. Retrieved from https://www.plateaustate.gov.ng/ministries/min-commerce-\&-industries

26. Ministry of Housing and Urban Development plateau state. (2019). About. Retrieved from https://www.plateaustate.gov.ng/ministries/min-housing-and-urban-dev

27. Moore, E. A. (2019). Addressing Housing Deficit in Nigeria: Issues, Challenges and Prospects. Economic and financial review, 57(4), 201-222.

28. Murray, C., \& Pearson, R. (2008, July). Innovative uses of housing cooperative assets. Retrieved from https://auspace.athabascau.ca/bitstream/handle/2149/1807/BALTA\%20A1\%20-\%20Coop\%20Housing\%20Report\%20-\%20F.pdf?sequence=1\&isAllowed=y

29. Ndubueze, 0. J. (2009). Urban housing affordability and housing policy dilemmas in Nigeria (Doctoral dissertation). Retrieved from http://humanitarianlibrary.org/sites/default/files/2013/08/Ndubueze09PhD.pdf

30. Northcountry Cooperative Foundation. (2003). Cooperative Housing Toolbox: A Practical Guide for Cooperative Success. Retrieved from 
https://www.nasco.coop/sites/default/files/srl/Housing_Toolbox_Practical_guide_for_success.p df

31. Nweze, N. J. (2003). Cooperative promotion in rural communities: The project approach. Nigerian Journal of Cooperative Studies, 2(2), 73-86.

32. Odhiambo, B. (2003). Determinants of customer satisfaction for mobile phone subscribers in Nairobi (Master's thesis). Retrieved from

http://erepository.uonbi.ac.ke/bitstream/handle/11295/22154/Odhiambo_Determinants\%20 of\%20Customer\%20Satisfaction\%20for\%20Mobile\%20Phone\%20Subscribers\%20in\%20Nair obi.pdf;sequence=3

33. Olanda, J. (2006). Leadership Behaviour, Job satisfaction, Organisational Commitment, Service Quality and Customer Satisfaction in manufacturing sector (Master's thesis), University of Nairobi, Kenya.

34. Olayinka, C. O., Samuel, A. O., \& Durodola,O, D. (2016). Empirical Determination of Co-operative Housing Intervention Methods in Lagos Metropolis. Covenant Journal of Research in the Built Environment, 4(1), 49-66.

35. Oliver, R. L. (1999). Whence Consumer Loyalty? Journal of Marketing, 63, 33. doi: $10.2307 / 1252099$

36. Oloke, O. C., Oni, A. S. Oletubo, Oletube, A. A., Opoko, A. P., \& Ogunde, A. O. (2017). Empirical Assessment of Success Rate of Cooperative Societies' Housing Provision in Lagos State, Nigeria. International Journal of Humanities and Social Science, 7(3), 1-8.

37. Oluwole Oyewole, M. (2010). Housing development finance through cooperative societies. International Journal of Housing Markets and Analysis, 3(3), 245-255. doi:

10.1108/17538271011063906

38. Oyalowo, B. (2018). An assessment of co-operative societies and housing supply in Lagos State (Doctoral thesis), University of Lagos. Retrieved from https://ir.unilag.edu.ng/bitstream/handle/123456789/3249/4_Thesis.pdf?sequence=2\&isAllo wed $=\mathrm{y}$

39. Robertsen, K., \& Theisen, T. (2009). The Impact of Financial Arrangements and Institutional Form on Housing Prices. The Journal of Real Estate Finance and Economics, 42(3), 371-392. doi: 10.1007/s11146-009-9213-z

40. Sazama, G. W. (2000). Lessons from the History of Affordable Housing Cooperatives in the United States: A Case Study in American Affordable Housing Policy. The American Journal of Economics and Sociology, 59(4), 573-608.

41. Shut, T. T. (2014). An evaluation of the strategies of rural development programmes in plateau state 1999-2010 (Doctoral dissertation). Retrieved from https://irepos.unijos.edu.ng/jspui/bitstream/123456789/480/1/Eva\%20Pol\%20Thesis.pdf

42. Sun, W., Zheng, S., Geltner, D. M., \& Wang, R. (2016). The Housing Market Effects of Local Home Purchase Restrictions: Evidence from Beijing. The Journal of Real Estate Finance and Economics, 55(3), 288-312. doi: 10.1007/s11146-016-9586-8

43. Tesfaye, A. (2007). Problems and prospects of housing development in Ethiopia. Property Management, 25(1), 27-53. doi: 10.1108/02637470710723245

44. UN-HABITAT. (2018). Adequate housing and slum upgrading. Retrieved from https://unhabitat.org/sites/default/files/2020/06/indicator_11.1.1_training_module_adequate_ housing_and_slum_upgrading.pdf

45. UN-HABITAT. (2010). The Organisation, Management and Finance of Housing Cooperatives in Kenya. Retrieved from https://mirror.unhabitat.org/pmss/getElectronicVersion.asp?nr=3001\&alt=1 
46. Yakub, A. A, Salawu, A. O., \& Gimba, S. D. (2012). Housing delivery via housing cooperatives as a tool towards achieving national development: an empirical study. Retrieved from https://bit.ly/3i9NRaH 